\title{
Effect of manganese and ascorbic acid on the growth and yield of faba bean (Vicia faba L.)
}

\author{
Hand Jawad Kadiem \\ Plant Production \\ Technical College of Applied Sciences \\ Sulaimani Polytechnic University \\ Halabja, Kurdistan Region, Iraq \\ Hindjawad20@gmail.com
}

\author{
Hawrez Ali Nadir \\ Plant Production \\ Technical College of Applied Sciences \\ Sulaimani Polytechnic University \\ Halabja, Kurdistan Region, Iraq \\ Hawrez.nadir@spu.edu.iq
}

\author{
Ali Abbas Khraibet \\ Plant Production \\ Technical College of Applied Sciences \\ Sulaimani Polytechnic University \\ Halabja, Kurdistan Region, Iraq \\ ali_altai65@yahoo.com
}

\begin{abstract}
This study was carried out in the field of Halabja Technical College of Applied Sciences, Sulaimani Polytechnic University, during the year 2015-2016. The objective of the study is to investigate the effect of the foliar application of manganese and ascorbic acid on the growth and yield of (Vicia faba L.).The field experiment was included nine concentrations and combination Mn and AsA was applied, using complete randomized block design with three replicates. The highest value of yield and the number of branches per plant were $146.66 \mathrm{gm}, 4.11$ when plant applied Mn 40 ppm+ AsA $60 \mathrm{pp}\left(\mathrm{T}_{9}\right)$. The maximum number of pods per plant (14.47) was given from $T_{9} \mathrm{Mn} 20 \mathrm{ppm}+\mathrm{AsA} 60 \mathrm{ppm}$. The highest seed per pods was 2.26 obtained from $\left(T_{8}\right)$, and the maximum 100seeds weight was received from $T_{2}$ AsA $30 \mathrm{ppm}(45.43 \mathrm{gm})$. Thus, the greatest weight of pods was found from control and $T_{2}$ AsA 30ppm $(13.4 \mathrm{gm})$. The most length of pods and the height of plant were given from both $\left(T_{4}\right) \mathrm{Mn} 20 \mathrm{ppm}$ and $\left(T_{3}\right)$ AsA $60 \mathrm{ppm}(9.49 \mathrm{~cm})(106.87 \mathrm{~cm})$ respectively. The lowest seed number per pods, 100-seed weight and length of pods were given from control, $T_{3}$ and $T_{5}(1.71,33.12 \mathrm{gm}$ and $8.06 \mathrm{~cm})$ respectively. Then $T_{5}(\mathrm{Mn20ppm}+$ AsA 30ppm) have given the minimum yield, weight of pods, plant height, number of branches per plant (contributory wit-h $T_{7}$ ) and number of pods per plant ( $41.66 \mathrm{gm}, 10.10 \mathrm{gm}, 81.98 \mathrm{~cm}, 3.25$ and 4.46). As a result, in this study, we can recommend to conduct more studies on micronutrients for different crops.
\end{abstract}

Keyword: Faba bean, Manganese, Ascorbic acid, Yield, Growth, Foliar application.

\section{INTRODUCTION}

Faba bean (Vicia faba L.) is a Mediterranean region cultivar crop; it belongs to the family of (Fabaceae) and consists of two subspecies Vicia faba L. and Vicia faba Paucijuga Murat [4, 8]. Consequently, among coolseason crops faba bean is ranked fourth after pea, chickpea and lentil $[1,5,8]$. [6] reported that the faba bean is an ancient crop from the Mediterranean.

Despite faba is well adapted to a wide range of ecological conditions and has become a basic inter crop in winter, the declining soil fertility due to loss of organic matter and cultivate them for the restoration $\mathrm{N}$ (nitrogen), and fixation $\mathrm{N}$ from faba bean increased the nitrogen to the next crop in the soil [1]. Faba bean contains protein, carbohydrate, fat, fiber, vitamins, and minerals, condense tannins, vicine and convicine which are used as food from human and animal [7, 9, 10, 16]. Faba bean from Kurdistan-Iraq is cultivated for food as vegetable pods and dried beans, and is grown in rainfall area and somewhere irrigation condition can be cultivated in the different climatic zone [12]. Faba bean cultivation for higher yield has a high requirement for major element especially nitrogen [2]. The faba bean traditionally is cultivated in Kurdistan-Iraq. The faba bean intercropping is worldwide applied for increase yield and withstanding pest and diseases from the soil [3].

Foliar application of fertilizer is to increase yield and quality of faba bean, and it has more impact than the application from the soil when the root withstands uptake the nutrition [13]. However, micro elements applied from the foliar are better than the soil $[13,14]$. Thus, both of manganese and ascorbic acid lead to increase yield in to the plant and shear in to the plant cells [15]. Manganese has a major role in faba bean such functions as photosynthesis and complex protein synthesis, manganese has also an important role in faba bean seed [15].

Cultivation area from in Iraq 2008 is 1250 hectors, and approximately production is (7000) tons [11] and [12]. The target of excellent plant nutrition is to guarantee that crops uptake the amount of nutrients need for optimal yield [15]. The aim of the study was to study the effect of the manganese and ascorbic acid on growth and yield of (Vicia faba L.) in order to develop and upgrade the production of the crop in Halabja, Kurdistan region Iraq.

\section{MATERIAL AND METHOD}

The field experiment was carried out in the field of Halabja Technical College of Applied Sciences, Sulaimani Polytechnic University, during the year 20152016. The complete randomized block design was used for the experiment with three replications. In this study, nine concentrations were used including controls sprayed by the distilled water (Table 1). Tow sprays were used, the first one month after germination, and the second was 15 days after that. The plants totally have being sprayed until wet them, using the hand-held sprayer, and manganese sulphate $\mathrm{MnSO}_{4}-5 \mathrm{H}_{2} \mathrm{O}$ as source.

Table 1: Concentration of manganese and ascorbic acid used in this study.

\begin{tabular}{|c|c|c|}
\hline$\stackrel{\mathscr{U}}{0}$ & \multicolumn{2}{|c|}{ Concentration (ppm) } \\
\hline$\stackrel{D}{\oplus}$ & Ascorbic acid & Manganese \\
\hline $\mathrm{T} 1$ & \multicolumn{2}{|c|}{ Control(Distilled Water) } \\
\hline $\mathrm{T} 2$ & 30 & - \\
\hline
\end{tabular}




\begin{tabular}{|c|c|c|}
\hline T3 & 60 & - \\
\hline T4 & - & 20 \\
\hline T5 & 30 & 20 \\
\hline T6 & 60 & 20 \\
\hline T7 & - & 40 \\
\hline T8 & 30 & 40 \\
\hline T9 & 60 & 40 \\
\hline
\end{tabular}

The experimental unit includes two rows with width $60 \mathrm{~cm}$ width and $5 \mathrm{~m}$ length. The distance between plants was $25 \mathrm{~cm}$. The cultivar used in this study was local variety. The experiment was sown on November17, 2015, after conducting all the soil crop managements for this crop

The effect of the treatments was studied, and data recorded on yield and yield attributes of the crop on ten randomly selected plants and the mean of each of number of pods/plant, weight of pods $(\mathrm{gm})$, yield $(\mathrm{gm})$, number of seeds/pod, length of pod $(\mathrm{cm})$, plant height $(\mathrm{cm})$, fresh weight 100 seeds $(\mathrm{gm})$, and number of branches/plant were evaluated. The harvesting was carried out from April. The Statistical analysis were done by one way ANOVA, and the comparisons of means realized by the Bonferroni's multiple comparison range test at $\mathrm{p}<0.05$, by the (GraphPad Prism version 5.00) program.

\section{RESULTS AND DISCUSSION}

Collected data for yield analysis from foliar applications by manganese and ascorbic acid showed non-significant differences between the treatments at $p<0.05$ (Figure 1). The highest yield was found in the treatment $\mathrm{T}_{9} \mathrm{Mn}+$ Ascorbic acid 40ppm+60ppm (146.66 gm). the lowest was recorded from treatment $\mathrm{T}_{5}$ Manganese+ Ascorbic acid $20 \mathrm{ppm}+30 \mathrm{ppm}$ (41.66 gm), and other treatments $\mathrm{T}_{2}, \mathrm{~T}_{4}, \mathrm{~T}_{3}, \mathrm{~T}_{7}, \mathrm{~T}_{6}, \mathrm{~T}_{8}$ and $\mathrm{T}_{1}(145.66,137.77,131.66$, $128.77,109.30,108.33$ and $91.0 \mathrm{gm})$ respectively are found between the two values. The results were with other researches results [15], but contrast with [2].

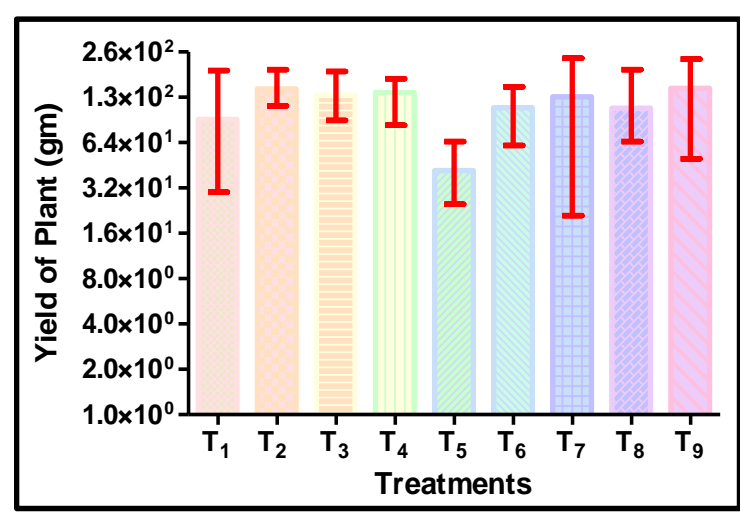

Figure 1: The effect of manganese and ascorbic acid on the yield of plan in (gm). The columns show the mean of the yield and Error bar show the range of the yield.

There were no significant differences between the treatments at $\mathrm{p}<0.05$ in the number of seeds per pod Maximum number of seeds per pod was recorded from $\mathrm{T}_{8}$ Manganese 40ppm + Ascorbic 30 ppm (2.26 seeds) and the minimum number of seeds per pod was recorded from control (1.71 seeds) (Figure 2). That local species of faba bean used for the study contain one or two seeds, but very tasty, and the average numbers of seed per pods are the same constant character for the cultivar species. The other treatments $\mathrm{T}_{6}(2.02$ seeds $), \mathrm{T}_{4}(1.97$ seeds $), \mathrm{T}_{9}$ (1.95 seeds), $\mathrm{T}_{2}$ ( 1.93 seeds), $\mathrm{T}_{7}$ (1.92 seeds), $\mathrm{T}_{5}$ (1.90 seeds) and $\mathrm{T}_{3}$ (1.86 seeds) are located between the two values. Comparable result was found by $[8,20,21$, and 22] in faba bean, [19] in garden bean.

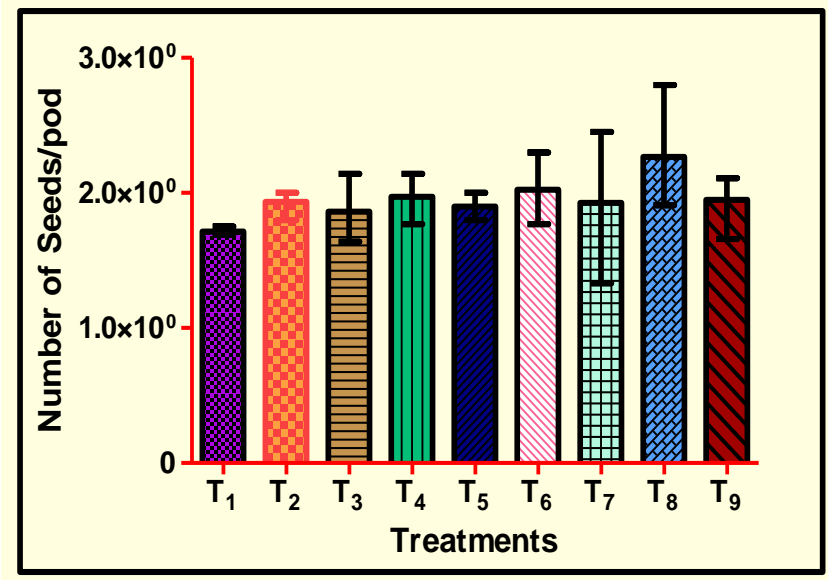

Figure 2: Effect of manganese and ascorbic acid on the number of seeds/pod.

There were no significant differences between the treatments at $\mathrm{p}<0.05$ in the number of seeds/pod.

The maximum weight for hundred seeds was recorded from treatments of $\mathrm{T}_{2}$ Ascorbic acid $30 \mathrm{ppm}$. (45.43gm), the minimum hundred seeds weight was recorded from the control $(36.33 \mathrm{gm})$ and the other treatments $\mathrm{T}_{9}$ $\mathrm{Mn} 40 \mathrm{ppm}+$ AsA 60ppm (41.43gm), $\mathrm{T}_{4} \mathrm{Mn} 20 \mathrm{ppm}$ (41.12gm), $\mathrm{T}_{6} \mathrm{Mn} 20 \mathrm{ppm}+$ AsA 60ppm (41.10gm), $\mathrm{T}_{7}$ Mn $40 \mathrm{ppm}$ (41.05 gm), $\mathrm{T}_{8}$ Mn 40ppm+AsA 30ppm (37.00gm), $\mathrm{T}_{5} \mathrm{Mn} 20 \mathrm{ppm}+$ AsA 30ppm (38.86gm), are located between the two values (Figure 3). [8, 21] worked on the faba bean obtained similar results. [19] was cited from [8] stating that the growing seasons affect the branch number per plant, it is caused to reduce the yield.

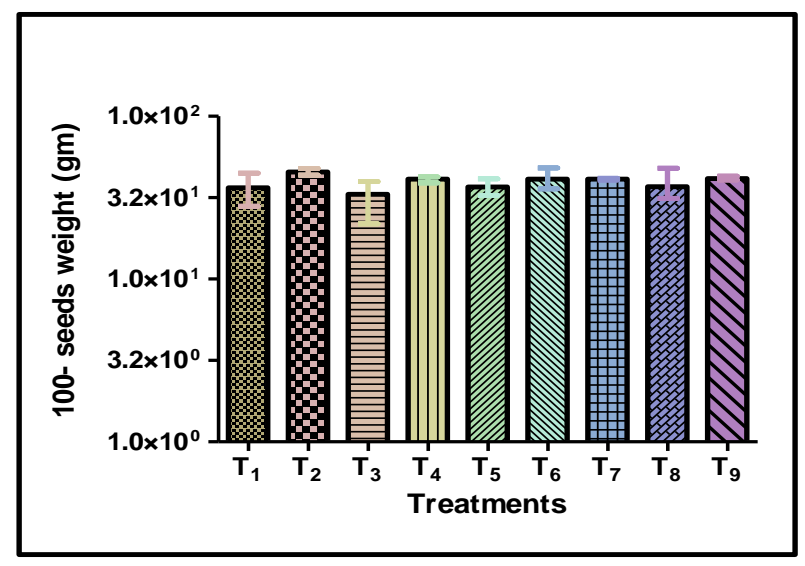

Figure 3: Effect of manganese and ascorbic acid on the 100 seeds weight $(\mathrm{gm})$.

Information from (Figure 4) explain the weight of pods (gm), and the comparison between treatments dose not appeared significant differences at $p<0.05$. However, the 
highest weight was obtained from treatments $\mathrm{T}_{1}$ control and $\mathrm{T}_{2}$ application ascorbic acid 30ppm (13.4 gm), and the lowest was given from treatment $\mathrm{T}_{5}$ foliar application $\mathrm{Mn} 20 \mathrm{ppm}+\mathrm{AsA} 30 \mathrm{ppm}$ (10.10 gm).That results are contrast with [12]. So, the result revealed by the application of manganese and ascorbic acid did not affect the weight of pods, and these results is in agreement with [18] worked on faba bean with exogenous application of salicylic acid.

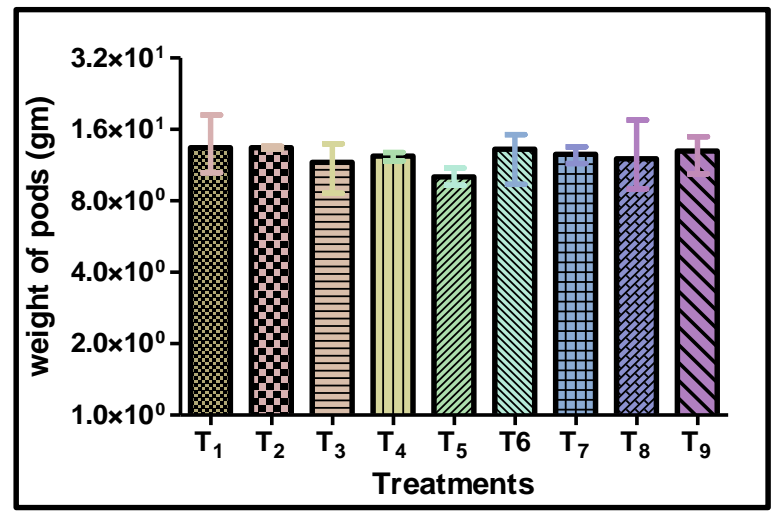

Figure 4: Effect of manganese and ascorbic acid on the weight of pods per (gm).

No significant differences were appeared between the treatments at $\mathrm{p}<0.05$ regarding the pod length. Foliar application of $\mathrm{T}_{4}$ manganese $20 \mathrm{ppm}$ on faba bean recorded the longest length of pod $(9.49 \mathrm{~cm})$, and that result is not a significant different comparison to the other parameters, the shortest length of pods was recorded from control $(8.06 \mathrm{~cm})$ and the other treatments $\mathrm{T}_{6}(9.43 \mathrm{~cm}), \mathrm{T}_{9}(9.22 \mathrm{~cm}), \mathrm{T}_{8}(9.16 \mathrm{~cm}), \mathrm{T}_{3}(9.15 \mathrm{~cm})$, $\mathrm{T}_{2}(9.03 \mathrm{~cm}), \mathrm{T}_{7}(8.76 \mathrm{~cm})$ and $\mathrm{T}_{5}(8.15 \mathrm{~cm})$ are located between the two values (Figure 5 ). The results agree with $[8,22]$ in faba bean and [16] in green bean. Pod length is directly related to the genetic factors [22].

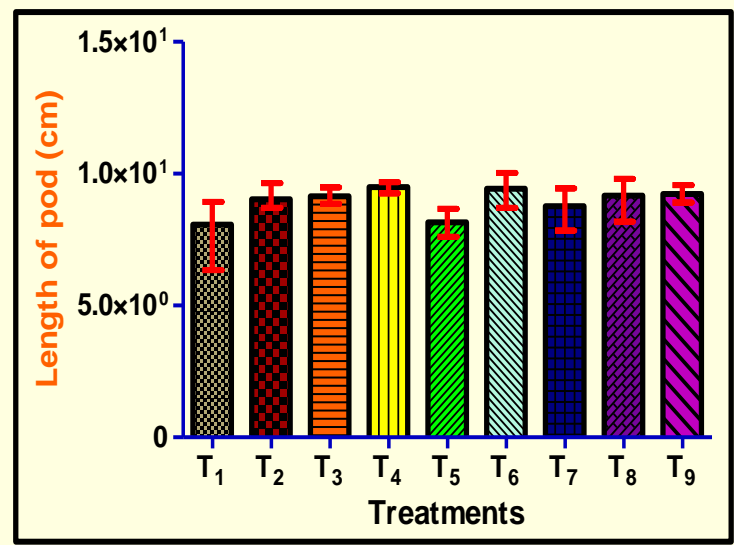

Figure 5: Effect of manganese and ascorbic acid on the length of pods $(\mathrm{cm})$.

Plant height from different parameters were applied from the study; there was no significant interaction between parameters at $p<0.05$ (Figure 6). The highest plant was given from treatment $T_{3}$ foliar application by ascorbic acid $60 \mathrm{ppm}(106.87 \mathrm{~cm})$, and the lowest was given from treatment $\mathrm{T}_{5}$ when applied Mn 20ppm and AsA 30ppm
$(81.98 \mathrm{~cm})$. Approximately, the similar result were found from [21].That result is contrast with those [20] worked on 10 genotypes of faba bean, and the maximum record from was $(50 \mathrm{~cm})$ and [16] in green bean.

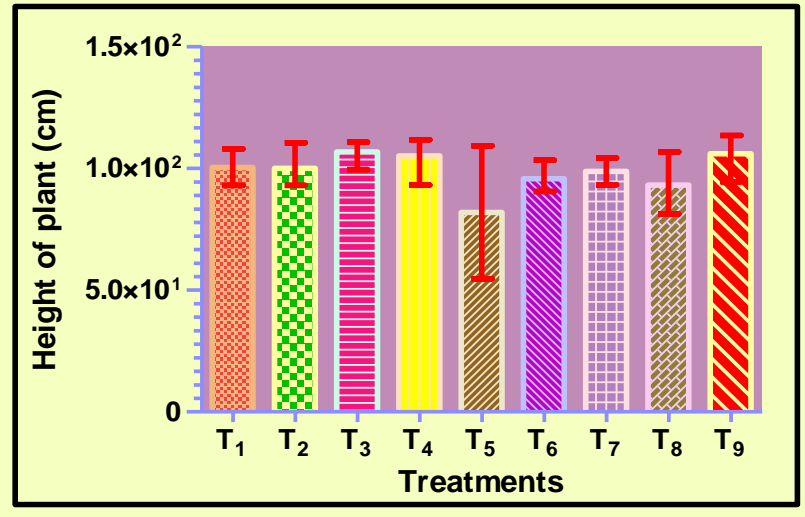

Figure 6: Effect of manganese and ascorbic acid on the height of plant $(\mathrm{cm})$

The addition of manganese and ascorbic acid at different concentrations had no significant effect on the number of plant branches in faba bean at $p<0.05$ (Figure7). The highest number of branches was recorded from treatment $\mathrm{T}_{9} \mathrm{Mn}$ 40ppm and AsA acid 60ppm (4.11), while the minimum value was 3.25 by each of $\mathrm{T}_{5} \mathrm{Mn} 20 \mathrm{ppm}$ and AsA 30ppm and $\mathrm{T}_{7} \mathrm{Mn} 40 \mathrm{ppm}$ and the other treatments $\mathrm{T}_{2}(3.83), \mathrm{T}_{3}(3.41), \mathrm{T}_{8}(3.40), \mathrm{T}_{4}$ and $\mathrm{T}_{6}(3.35), \mathrm{T}_{1}(3.33)$ are between the two values. These results are in agreement with those of [12]. Similar results were found by $[8,21]$ that have worked on different genotypes of faba bean.

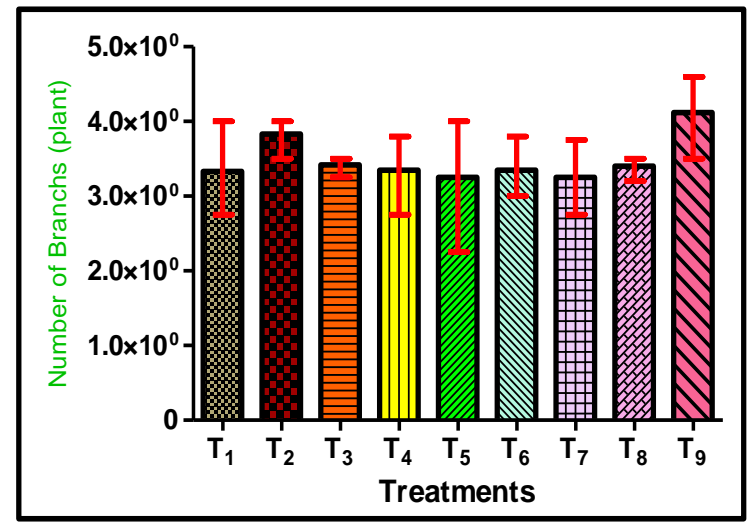

Figure 7: Effect of manganese and ascorbic acid on the number of branches were grown on the plant.

There were no significant differences between the treatments in the numbers of pods per plant at $p<0.05$ (Figure 8). The highest number of pods per plant was found in $\left(\mathrm{T}_{9}\right) \mathrm{Mn}$ 40ppm and AsA acid 60ppm (4.46), and the lowest was recorded in treatment $\mathrm{T}_{5} \mathrm{Mn} 20 \mathrm{ppm}$ with AsA $30 \mathrm{ppm}$ (6.23), and the other treatments T7 (24.40),T5, (13.56) T3, (13.36) $\mathrm{T}_{2}$, (12.93) $\mathrm{T}_{8}$, (11.56) $\mathrm{T}_{4}$, (11.16) $\mathrm{T}_{1}$ and (9.36) $\mathrm{T}_{6}$ are between the two values. Similar results were found with [16] study on faba bean and applied phosphorus fertilizers and foliar application with zinc. [22] reported 21.6 to 19.2 pods/plant for faba 
bean genotypes in Eastern Africa, and [8] reported 9.6 to 6.7 pods/plant for faba bean application method of phosphorus in faba bean in the absence of moisture stress, and also [17] reported 4.67 to 19.33 pods per plant applying zinc, iron and manganese on green beans, and finally [21] reported to 3.6 to 10.0 pods per plant working on faba bean (Vicia faba L.) in a shortseason Mediterranean-type environment.

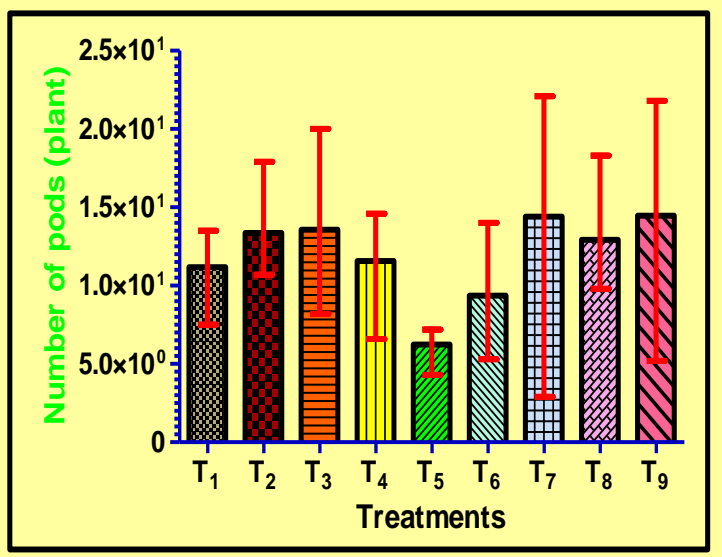

Figure 8: Effect of manganese and ascorbic acid on the number of pods per plant.

\section{CONCLUSION}

The results of this study have indicated that there was no significant effect for the addition of Manganese and Ascorbic acid on the characterizes of growth and yield for faba bean. Although, it is summarized that combination of the foliar application of manganese and ascorbic acid generally leads to the increasing of yield and it's components for faba bean. We suggest that more studies will be better about foliar application with another concentration of different microelements in the future.

\section{REFERENCES}

[1] A. Magdi, T. Horiuchi, and S. Oba. "Evaluation of the SPAD value in faba bean (Vicia faba L.) leaves in relation to different fertilizer applications." Plant Production Science 6.3, pp. 185189, 2003.

[2] M. H. Hendawey and Younes A. M. A., "Biochemical evaluation of some faba bean cultivars under rainfed conditions at El-Sheikh Zuwayid." Annals of Agricultural Sciences 58.2, pp. 183-193, 2013.

[3] F. Fenliang, F. Zhang, Y. Song, J. S. Xingguo B.T. Guo, and L. Li."Nitrogen fixation of faba bean (Vicia faba L.) interacting with a non-legume in two contrasting intercropping systems." Plant and Soil 283.1-2, pp. 275-286, 2006.

[4] T.,Cengiz. "Estimates of broad-sense heritability for seed yield and yield criteria in faba bean (Vicia faba L.)." Hereditas 140.3 , pp. 222-225, 2004.

[5] A.M. Torres, C.M. Avila, N. Gutierrez, C. Palomino and M.T. Moreno. "Marker-assisted selection in faba bean (Vicia faba L.)." Field crops research 115.3, pp. 243-252, 2010.

[6] D. Gerard, S. B. M. Baum, B. Redden, M. Sadiki, M. J. Suso, M. Vishniakova, and X. Zong. "Diversity maintenance and use of Vicia faba L. genetic resources." Field Crops Research 115, no. 3,pp. 270-278, 2010.

[7] C. Katell, P. Marget, C. Peyronnet, B. Carrouee, P. Arese, and G. Duc.. "Nutritional value of faba bean (Vicia faba L.) seeds for feed and food. "Field Crops Research, 115(3), pp. 329-339, 2010

[8] M. A. Turk, and A. M. Tawaha. "Impact of seeding rate, rate and method of phosphorus application in faba bean (Vicia faba L. minor) in the absence of moisture stress." Biotechnologie, agronomie, société et environnement 6.3, pp.171-178, 2002.
[9] E. Sayed and H. E. Ahmed. "Impact of magnetic water irrigation for improve the growth, chemical composition and yield production of broad bean (Vicia faba L.) plant." American journal of experimental agriculture 4.4, pp.476, 2014.

[10] L. A. Rubio, G. Gardocz, S. Bardocz, P. Dewey and A. Pusztai. "Nutritional response of growing rats to faba beans (Vicia faba L., minor) and faba bean fractions". British Journal of Nutrition, 66(3), pp. 533-542, 1991.

[11] FAOSTAT "Food and Agriculture Organization of The United Nations". http:// faostat. Fao. Org/site/ s67/ Desk, 2000. [Online]. J. Agri. Ro.pp. 73(4): pp.1685-1699.

[12] , A. A. Abdulla, "Effect of foliar spray of citric acid on the growth and green yield of broad bean (Vicia faba L.) growth in southern Iraq". Journal of Basrah Researches Sciences, 39(1B), p. 1817-2695, 2013.

[13] M. A. Atiia , M. A AbdAlla, S.M.M. Allam. "Effect of zinc and cobalt applied with different methods and rates on the yield components of Vicia faba L." WWJMRD, 2(2), pp.52-58, 2016.

[14] , A. A. El-Hosary, and S. A. S. Mehasen. "Effect of foliar application of zinc on some new genotypes of faba bean." Annals of Agric. Sc., Moshtohor 36.4, pp. 2075-2086.1998.

[15] P. Sharifi, and M. Paymozd. "Effect of zinc, iron and manganese on yield and yield components of green beans." Current Opinion in Agriculture 5.1, pp.15, 2016.

[16] S. P. Loss, K. H. M. Siddique, R. Jettner, and L. D. Martin "Responses of faba bean (Vicia faba L.) to sowing rate in southwestern Australia. I. Seed yield and economic optimum plant density." Australian Journal of Agricultural Research 49.6, pp. 989-998, 1998

[17] S.A. Orabi, B.B. Mekki and F.A. Sharara. "Alleviation of adverse effects of salt stress on faba bean (Vicia faba L.) plants by exogenous application of salicylic acid." World Appl Sci J 27.4, pp. 418-427, 2013.

[18] T. Thomson, G.S. Patel, J.B. Thakar and K.S. Pandya "Effect of Foliar Application of Acetyl Salicylic Acid and Ascorbic Acid on Yield and Yield Attributes of Garden Pea (Pisum sativum L.) cv. Bonneville." Int. J. Curr. Microbiol. App. Sci 6.6, pp.1982-1986, 2017.

[19] J. Mwanamwenge, S. P. Loss, K. H. M. Siddique and P. S. Cocks. "Growth, seed yield and water use of faba bean (Vicia faba L.) in a short-season Mediterranean-type environment." Australian Journal of Experimental Agriculture 38.2, pp.171-180, 1998.

[20] , M. O Al-Rifaee. H. D., Munir A. Turk, and A.M. Tawaha "Effect of seed size and plant population density on yield and yield components of local fababean (Vicia faba L. major)." International Journal of Agriculture and Biology 6.2, pp.294-299, 2004.

[21] T. E. Kubure, C.V. Raghavaiah, and I. Hamza. "Production potential of faba bean (Vicia faba L.) genotypes in relation to plant densities and phosphorus nutrition on vertisols of central highlands of West Showa Zone, Ethiopia, east Africa." Advances in Crop Science and Technology, pp.1-9, 2016.

[22] N.K.B. El-Gizawy and S.A.S. Mehasen. "Response of faba bean to bio, mineral phosphorus fertilizers and foliar application with zinc." World Applied Sciences Journal 6.10,pp..1359-1365, 2009. 